7. Reprod. Fert. (1968) 16, 271-281.

\title{
THE EFFECTS OF PROGESTERONE, TESTOSTERONE AND ERGOCORNINE ON NON-PREGNANT AND PREGNANT GUINEA-PIGS
}

\author{
RUTH DEANESLY \\ A.R.C. Institute of Animal Physiology, Babraham, Cambridge
}

(Received 30th November 1967)

\begin{abstract}
Summary. In guinea-pigs absorbing $0.1 \mathrm{mg}$ or more progesterone daily from solid, subcutaneous tablets, follicles grow and regress normally as do existing corpora lutea, but ovulation is completely inhibited. The uterus, in the absence of cyclic changes, is continuously stimulated by ovarian oestrogens in progesterone-treated animals. It enlarges, sometimes becoming enormous, and shows various pathological changes. These are absent from the uteri of ovariectomized animals treated with progesterone. Five males which absorbed 0.26 to $1.7 \mathrm{mg}$ progesterone daily for 30 to 64 days had normal reproductive organs.

Testosterone propionate, similarly administered, also inhibits ovulation; additionally it leads to a reduction in follicle growth and ovary size. Both steroids showed steady, slow rates of absorption as determined from tablet weights before and after implantation.

Ergocornine, which is said to inhibit corpus luteum secretion in rats, had no such effect on corpora lutea in non-pregnant and pregnant guinea-pigs, when injected in solution.
\end{abstract}

\section{INTRODUCTION}

Lipschutz (1950) and others have emphasized the differences between pituitaryovarian relationships in the guinea-pig and those in rats and mice. The present experiments on the effects of progesterone and other substances in non-pregnant and pregnant guinea-pigs were planned to provide information on the control of ovulation and the functional corpus luteum together with the accompanying changes in the uterus and vagina.

\section{MATERIAL AND METHODS}

These were the same as in previous work (Deanesly, 1963, 1967). Compressed tablets of progesterone and testosterone propionate of known weight were placed under the skin and were dried and reweighed to the nearest $\mathrm{mg}$ or tenth of a mg at the time of removal, so that the average daily absorption could be calculated. In other animals progesterone was injected subcutaneously as a $10 \mathrm{mg} / \mathrm{ml}$ solution in arachis oil. Ovaries were examined at autopsy, fixed in 
Bouin's fluid and sectioned serially at $7 \mu$. Uteri were weighed after fixation and transfer to $70 \%$ alcohol. The ergocornine methane sulphate was dissolved in $20 \%$ alcohol and injected subcutaneously.

\section{EXPERIMENTAL RESULTS IN NON-PREGNANT AND OVARIEGTOMIZED FEMALES AND IN MALES}

\section{PROGESTERONE}

\section{Progesterone tablets and plasma progesterone levels}

Absorption from the progesterone tablets, weights up to $50 \mathrm{mg}$, proceeded slowly at a steady, fairly uniform rate (Tables 1, 2 and unpublished data); tablets remained solid and could be cleaned and re-used with similar results. Rates of absorption varied with the initial size and number of the tablets implanted. Plasma progesterone levels remained low in all progesterone treated, non-pregnant, normal or ovariectomized animals whose blood was examined. These levels, 2 to $3 \mathrm{ng} / \mathrm{ml}$, were generally in the lower range of those recorded for non-pregnant guinea-pigs ( 1 to $13 \mathrm{ng} / \mathrm{ml}$ ) by Heap, Perry \& Rowlands (1967), but in ovariectomized animals with large amounts of progesterone (Table 2) they showed an appreciable rise, up to $25 \mathrm{ng} / \mathrm{ml}$ (Heap \& Deanesly, 1967).

\section{TABLE 1}

AVERAGE ABSORPTION FROM 27 TO $42 \mathrm{mg}$ PROGESTERONE TABLETS IN NON-PREGNANT GUINEA-PIGS, WITH UTERUS WEIGHTS AT AUTOPSY

\begin{tabular}{|c|c|c|c|c|c|}
\hline \multirow{2}{*}{$\begin{array}{l}\text { No. of } \\
\text { animals }\end{array}$} & \multicolumn{2}{|c|}{ Progesterone ( $m g$ ) } & \multirow{2}{*}{ Days } & \multirow{2}{*}{$m g / d a y$} & \multirow{2}{*}{$\begin{array}{l}\text { Uterus wt } \\
\quad(g)\end{array}$} \\
\hline & Implanted & Absorbed & & & \\
\hline $\begin{array}{l}1 \\
1 \\
3 \\
1 \\
6 \dagger \\
5 \ddagger \\
4 \$ \\
5 \\
2 \\
2\end{array}$ & $\begin{array}{l}30 \\
27 \\
32 \cdot 7 \\
42 \\
30 \cdot 5 \\
35 \cdot 2 \\
31 \cdot 5 \\
30 \cdot 2 \\
30 \cdot 5 \\
34\end{array}$ & $\begin{array}{l}3 \\
7 \\
9 \\
11 \\
11 \\
18 \cdot 6 \\
13 \cdot 5 \\
13 \cdot 2 \\
18 \cdot 5 \\
23 \cdot 5\end{array}$ & $\begin{array}{l}17 \\
24 \\
35 \\
37 \\
47 \\
47 \\
47 \\
51 \\
75 \\
99\end{array}$ & $\begin{array}{l}0.18 \\
0 \cdot 29 \\
0.26 \\
0.30 \\
0.23 \\
0.40 \\
0.29 \\
0.26 \\
0.25 \\
0.24\end{array}$ & $\begin{array}{c}* \\
* \\
1.07 \text { to } 4.59 \\
2.72 \\
\text { t } \\
1.10 \text { to } 2.51 \\
1.17 \text { to } 1.65 \\
1.34 \text { to } 22.50 \\
* \\
* \text { and } 13\end{array}$ \\
\hline
\end{tabular}

* Uterus unweighed, not exceptionally large.

+ Animals retained for return of cycle after tablet removal.

¥ Large parous females and $\$$ smaller females used in the study of body-weight and food intake.

\section{Inhibition of ovulation, etc.}

Cyclic females were each given one or two subcutaneous tablets of progesterone, totalling 27 to $42 \mathrm{mg}$ per animal, 6 or 7 days after oestrus in the middle of the luteal phase. Tablets were left in for 17 to 99 days, during which time no vaginal opening occurred. At autopsy, when the tablets were removed, large follicles were present but no corpora lutea were seen in the ovaries and none was found later in serial sections (Pl. 1, Fig. 1). Average daily absorption of progesterone varied from 0.18 to $0.40 \mathrm{mg}$, which was enough to inhibit 
ovulation, as recorded earlier by Dempsey (1937) in guinea-pigs. Luteinizing hormone $(100 \mu \mathrm{g} \mathrm{NIH-LH-s10)}$ injected subcutaneously could induce ovulation in the experimental females (Pl. 1, Fig. 2) as in normal cyclic ones (Deanesly, 1966a).

Inhibition of ovulation by exogenous progesterone has been recorded in rats, mice and other species (Rothchild, 1965). In these species, too, ovulation can be induced in the presence of progesterone by gonadotrophins, and follicular growth is not affected up to the pre-ovulatory stages.

Tablets were removed after 47 days from six females; vaginal opening after 4 or 5 days was followed by normal cycles. No attempt was made to determine the latest date in the cycle on which progesterone could stop ovulation, owing to slight variations in cycle length. Tablets put in on Day 11, however, were effective in two females.

Body weights and food intake were examined in two 47-day groups (Table 1); guinea-pigs continue growing almost throughout life, so that it was necessary to compare them weekly with control animals of corresponding body weights. No significant differences were found between the nine experimental and eight control females when average body weights and food intake were compared weekly during the 47-day experiment.

With a view to determining approximately the smallest daily absorption of progesterone which would inhibit ovulation, nine luteal phase guinea-pigs were given tablets ranging from 16 to $6 \mathrm{mg}$. No vaginal opening occurred while these remained in situ ( 30 to 34 days). Three animals killed after 34 days were anovulatory with somewhat enlarged uteri, up to $1.4 \mathrm{~g}$; absorption was 3.3 and $5 \mathrm{mg}$. In other animals tablets were removed and fertile matings took place at oestrus within 5 days. From two more females, killed after 13 days, when the current cycle would have been over, tablets of 3 and $6 \mathrm{mg}$ were not recovered, but there had been no oestrus or ovulation, and in one the uterus weighed $1.6 \mathrm{~g}$.

The results, taken together, showed that a daily absorption of $0.1 \mathrm{mg}$ or less sufficed to inhibit ovulation indefinitely. Total amounts absorbed from tablets of $4.4,4.8$ and $6.8 \mathrm{mg}$ over 39,20 and 20 days were $3.75,1.7$ and $2.9 \mathrm{mg}$ respectively.

\section{Effects on the uterus}

Inhibition of ovulation in the experimental animals was associated with growth of the uterus, sometimes to a pathological extent. Uterine weights are lacking for some animals where the enlargement was not conspicuous (Table 1), but from the available data it is clear that uteri weighed over $1 \mathrm{~g}$ in the experimental females as compared with 0.6 to $0.7 \mathrm{~g}$ in normal cyclic females. Growth of the uterus to about $2 \mathrm{~g}$ could occur in 23 or 25 days. The three largest uteri, 4.59, 22.5 and $13 \mathrm{~g}$, were in animals which had absorbed $9 \mathrm{mg}$ over 35 days, $11 \mathrm{mg}$ over 50 days and $23 \mathrm{mg}$ over 99 days, or averages of $0.25,0.22$ and $0.23 \mathrm{mg}$ daily. The last of these animals had embryonal placentomata in the ovary, similar to those described by Loeb (1932), as developing occasionally in atretic follicles, from parthenogenetic eggs. In later experiments on four mated but non-pregnant females, larger amounts of progesterone, up to $188 \mathrm{mg}$, 
were implanted, 6 to 8 days after oestrus, with results similar to those already described. Increased absorption of progesterone did not appear to accelerate or increase uterine growth.

The uteri were characterized by an increase in circular muscle and in stromal elements. The endometrium became oedematous and spaces appearing below the epithelium were gradually enclosed to form cysts (Pl. 2, Figs. 7 to 10). Glands were reduced in number and size. Some of the uteri were distended with fluid. There was a general resemblance to the uteri of the guinea-pigs which received continuous low oestrogen dosage, described and illustrated by Lipschutz and his colleagues (Lipschutz, 1950). Earlier Nelson (1936) had described fibroblastic proliferation in guinea-pig uteri after long-term treatment with oestrogens.

In the progesterone-treated animals with ovaries containing large follicles, sometimes of oestrous size, the uteri were probably reacting to a continuous secretion of ovarian oestrogen. This contrasts with the cyclic secretion in the normal female, evidenced by the low, luteal phase vaginal epithelium which only proliferates just before pro-oestrus (Deanesly, 1966c), especially in the final $24 \mathrm{hr}$ when the follicles undergo their maximum enlargement (Dempsey, 1937). In the experimental females the vaginal epithelium was always deeply mucified (Pl. 2, Fig. 11) as would be expected with a combination of progesterone and endogenous oestrogen (Deanesly, 1960).

\section{Corpora lutea}

The effects of progesterone on existing cyclic corpora lutea were examined in seven females. In the first three, tablets weighing 103, 89 and $88 \mathrm{mg}$ were placed subcutaneously 2 days after oestrus. Six days later, in mid cycle, the animals were killed and the corpora lutea were examined and measured and found to be normal; progesterone absorption was 5, 5 and $4 \mathrm{mg}$. Three other cyclic guinea-pigs each received 247 or $248 \mathrm{mg}$ progesterone 4 days after oestrus, the tablets being removed 5 days later. If the progesterone had inhibited or caused regression of the corpora lutea, oestrus should have recurred before the end of the normal cycle (Loeb, 1914; Dempsey, 1937), but actually the next oestrus took place 17,15 and 18 days after the previous one. Absorption was 9,10 and $14 \mathrm{mg}$, a relatively large amount over 5 days. Another guinea-pig,

\section{EXPLANATION OF PLATE 1}

Sections through guinea-pig ovaries and uteri $\times 28$.

Fig. 1. No. 61. Follicular development and absence of ovulation in ovary of animal which absorbed $5 \mathrm{mg}$ progesterone over 22 days.

FIG. 2. No. 17. Similar ovary from an animal which absorbed $8 \mathrm{mg}$ progesterone over 25 days. One day before autopsy it received $100 \mu \mathrm{g} \mathrm{LH}$ and a follicle was ruptured normally. Others show disorganized follicular epithelium.

Frg. 3. No. 23. Ovary of female which absorbed $23 \mathrm{mg}$ testosterone propionate over 20 days; only small follicles are present in the ovary which had lost weight.

Fig. 4. No. 258. Part of a transverse section through a normal uterus showing endometrium and muscle layers.

Fig. 5. No. 44. Transverse section through $300 \mathrm{mg}$ uterus of ovariectomized female which absorbed $15 \mathrm{mg}$ progesterone over 52 days. The uterus has contracted and shows epithelial cysts. 
PLATE
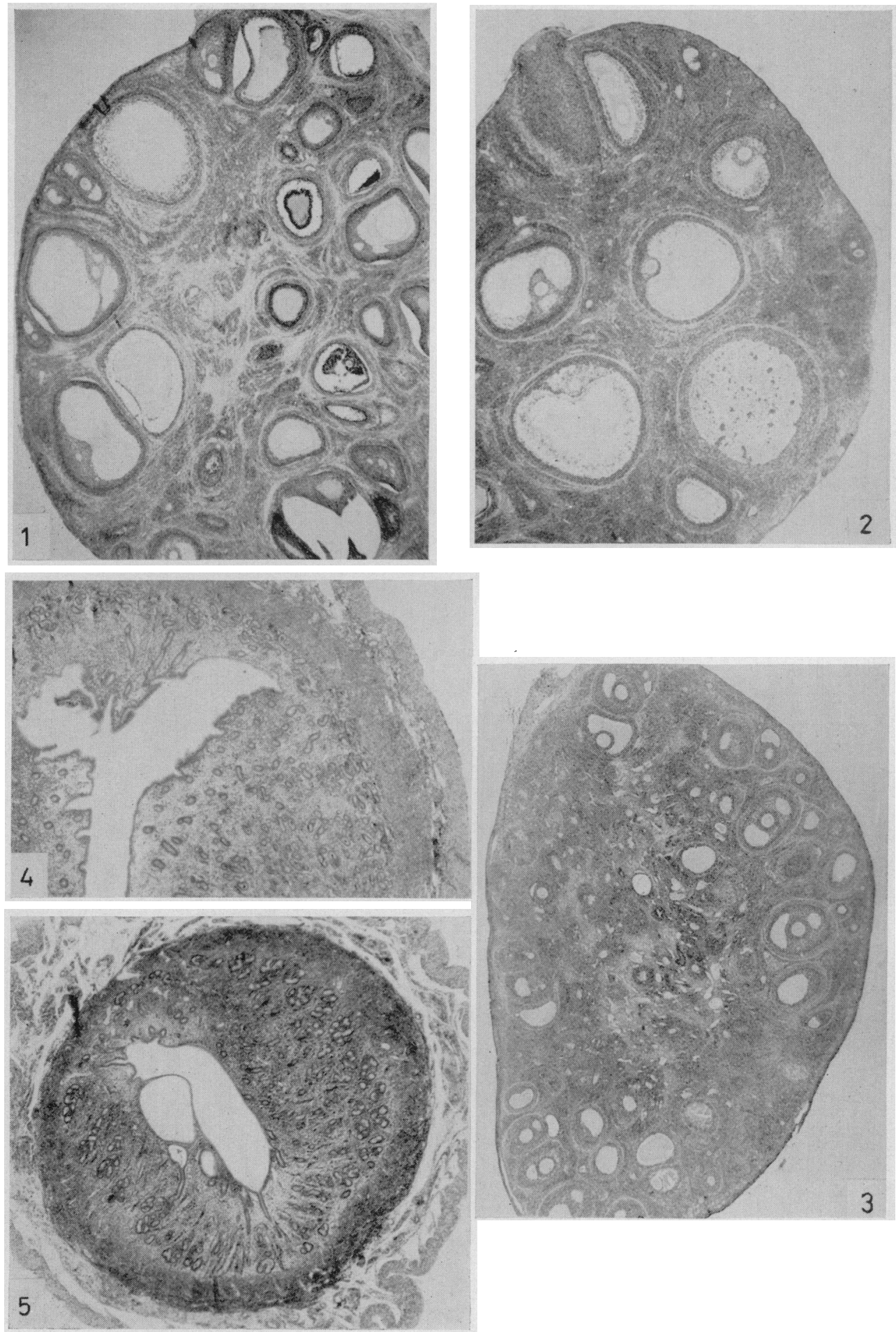
PLATE 2
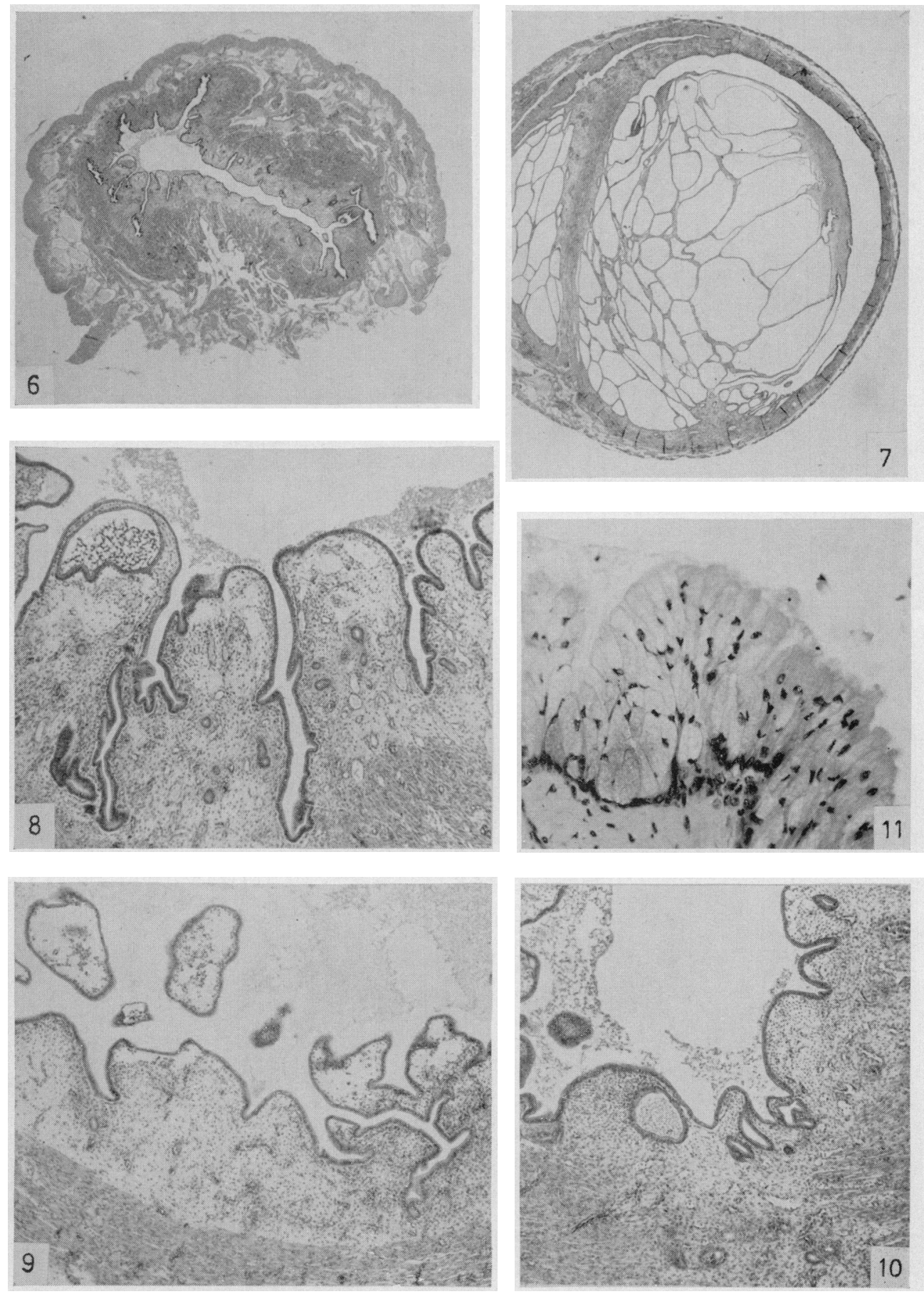

(Facing p. 275) 
given $10 \mathrm{mg}$ progesterone in oil by injection daily from Days 9 to 14 and killed 4 days later, had normally regressed corpora lutea, which had not been prolonged by the treatment.

\section{Ovariectomized guinea-pigs}

Eight ovariectomized guinea-pigs received progesterone tablets totalling 39 to $302 \mathrm{mg}$ over 12 to 76 days (Table 2). The uteri, though somewhat larger than in long-term ovariectomized animals, remained small and appeared normal, apart from the cysts which developed in the epithelium round the lumen. These cysts were similar to the ones described and illustrated by

TABLE 2

PROGESTERONE ABSORPTION AND UTERUS WEIGHTS IN EIGHT OVARIEGTOMIZED GUINEA-PIGS

\begin{tabular}{|c|c|c|c|c|c|c|}
\hline \multicolumn{2}{|c|}{ Tablets } & $\begin{array}{c}\text { Absorbed } \\
(\mathrm{mg})\end{array}$ & Days & $m g / d a y$ & $\%$ absorbed & $\begin{array}{l}\text { Uterus wt } \\
(\mathrm{g})\end{array}$ \\
\hline $\begin{array}{r}192 \\
80 \\
189 \\
173 \\
218 \\
302 \\
39 \\
186\end{array}$ & $\begin{array}{l}(5) \\
(2) \\
(5) \\
(4) \\
(5) \\
(6) \\
(1) \\
(5)\end{array}$ & $\begin{array}{r}15 \\
15 \\
25 \\
13 \\
73 \\
89 \\
15 \\
100\end{array}$ & $\begin{array}{l}12 \\
19 \\
21 \\
32 \\
47 \\
47 \\
52 \\
76\end{array}$ & $\begin{array}{l}1.25 \\
0.79 \\
1.19 \\
0.41 \\
1.55 \\
1.90 \\
0.29 \\
1.32\end{array}$ & $\begin{array}{r}7 \cdot 8 \\
18 \cdot 7 \\
13.2 \\
7.5 \\
33.5 \\
29.5 \\
38.7 \\
53 \cdot 8\end{array}$ & $\begin{array}{l}0.66 \\
0.50 \\
0 \cdot 31 \\
0 \cdot 69 \\
0 \cdot 40 \\
0 \cdot 40 \\
0 \cdot 30 \\
0.45\end{array}$ \\
\hline
\end{tabular}

Phelps, Burch \& Ellison (1938) in the uteri of ovariectomized guinea-pigs receiving $1 \mathrm{mg}$ testosterone propionate daily for 34 days. They are probably associated with the suppression of normal cyclic changes.

In progesterone-treated animals the vaginal epithelium was low, indicating absence of extra-ovarian circulating oestrogens. The progesterone plasma levels

\section{EXPLANATION OF PLATE 2}

Transverse sections through uteri and vagina of progesterone-treated guinea-pigs.

Fig. 6. No. 21. A very large (13 g) uterus from an animal which absorbed $23 \mathrm{mg}$ over 99 days, showing proportionate reduction of endometrium, few glands and great development of the muscle layers. $\times 3.9$.

Fig. 7. No. 9. Cystic enlarged uterus $(4 \cdot 6 \mathrm{~g})$ from an animal which absorbed $9 \mathrm{mg}$ over 66 days. $\times 6 \cdot 1$.

Fig. 8. No. 21. Part of Fig. 6 at a higher magnification showing vascular oedematous endometrium and a cyst. Circular muscle projecting into the endometrium can be seen below. $\times 39$.

Fig. 9. No. 40. Uterine endometrium from an animal which absorbed $11 \mathrm{mg}$ over 31 days. The uterus weighed $2.7 \mathrm{~g}$ and shows developing cysts next the lumen. Proportionately the endometrium is reduced and there are few glands. $\times 39$.

Frg. 10. No. 8. Uterine endometrium from another animal which absorbed $8 \mathrm{mg}$ over 35 days. The uterus weighed $1.51 \mathrm{~g}$ and shows another stage of oedema and cyst development. $\times 39$.

FIG. 11. No. 61. Mucified vaginal epithelium, resembling that of pregnancy, in an animal which absorbed $5 \mathrm{mg}$ progesterone over 22 days. $\times 195$. 
remained low but were roughly proportionate to the daily amounts absorbed (Heap \& Deanesly, 1967).

\section{Males}

Four males were each given a 48 - or $50-\mathrm{mg}$ subcutaneous progesterone tablet. One was killed after 30 days and the others after 64 days. All appeared normal and had large accessory glands and motile spermatozoa. Absorption was from 0.26 to $0.36 \mathrm{mg} /$ day. Another male had six progesterone tablets totalling $261 \mathrm{mg}$, but absorption of $65 \mathrm{mg}$ over 38 days also had no effect on the germinal or interstitial cells of the testis.

TABLE 3

ABSORPTION OF TESTOSTERONE PROPIONATE FROM THREE TO SEVEN SUBGUTANEOUS TABLETS

\begin{tabular}{|c|c|c|c|c|c|}
\hline \multicolumn{2}{|c|}{ Tablets } & $\begin{array}{c}\text { Absorption } \\
(\mathrm{mg})\end{array}$ & Days & $m g / d a y$ & $\%$ absorbed \\
\hline $\begin{array}{l}246 \\
156 \\
126 \\
154 \\
156 \\
158 \\
214 \\
164\end{array}$ & $\begin{array}{l}(7) \\
(4) \\
(3) \\
(5) \\
(5) \\
(5) \\
(5) \\
(4)\end{array}$ & $\begin{array}{l}11 \\
14 \\
16 \\
22 \\
23 \\
23 \\
30 \\
20\end{array}$ & $\begin{array}{r}7 \\
14 \\
20 \\
20 \\
20 \\
20 \\
20 \\
24\end{array}$ & $\begin{array}{l}1.59 \\
1.00 \\
0.80 \\
1.10 \\
1.15 \\
1.15 \\
1.50 \\
0.83\end{array}$ & $\begin{array}{r}4.5 \\
9.0 \\
12 \cdot 7 \\
14 \cdot 3 \\
14 \cdot 7 \\
14 \cdot 6 \\
14 \cdot 0 \\
12 \cdot 2\end{array}$ \\
\hline
\end{tabular}

\section{TESTOSTERONE PROPIONATE}

Effects on ovaries and accessory organs

Eight cyclic guinea-pigs were given subcutaneous tablets of testosterone propionate (Table 3 ) for periods of 7 to 24 days, beginning at oestrus (three) or in the first half of the luteal phase (five). Average absorption of testosterone ranged from 0.80 to $1.59 \mathrm{mg}$ daily. This inhibited vaginal opening and fresh ovulations in all cases, but testosterone given late in oestrus and left for 7 days (daily absorption $1 \mathrm{mg}$ ), did not interfere with normal development of the corpora lutea. After 14 to 24 days all corpora lutea had regressed.

The ovaries in these animals differed from those in the progesterone group by their reduced size (Pl. 1, Fig. 3); after 20 or more days the stroma appeared dense and the follicles, though variable, were mainly small with diameters up to $0.6 \mathrm{~mm}$ as compared with $1.18 \mathrm{~mm}$ in progesterone-treated animals. In the last three females, one ovary was removed from each before implantation of the tablets and the weights were compared with those of the second ovaries at the end of the 20-day experiment. The results were: normal ovaries 32, 49 and $37 \mathrm{mg}$, testosterone-treated ovaries 19,24 and $27 \mathrm{mg}$, indicating an average weight loss of about $40 \%$.

Examination of the vaginal epithelium showed various degrees of mucification, sometimes low mucified epithelium with abundant leucocytes. In the guinea-pig receiving the largest amount of testosterone (30 mg over 20 days) the uterus was enlarged approximately to oestrous size, but in the other animals 
no conspicuous uterine changes were observed. In an ovariectomized guineapig which absorbed $13 \mathrm{mg}$ over 14 days the vaginal epithelium was low, not mucified and the uterus was not enlarged. Testosterone, besides inhibiting ovulation, has a direct stimulating action on the uterine endometrium (Parkes, 1966), but the amounts required, e.g. $1 \mathrm{mg}$ daily as given by Phelps et al. (1938), are much higher than for oestrogens.

\section{ERGOCORNINE METHANE SULPHATE}

\section{Cycle length and corpora lutea}

Seven unmated females were injected 3 to 5 days after oestrus; two had $1 \mathrm{mg}$ and three had $2 \mathrm{mg}$ (in two successive daily doses). The cycle length was not affected and there was no premature return of oestrus. Two other females had three daily injections each of $2 \mathrm{mg}, 6,7$ and 8 days after oestrus; one was autopsied 1 day after the last injection and the ovary sectioned serially. The corpora lutea were normal in size and appearance. In the other female oestrus returned at the normal time, 9 days after the last injection.

\section{EXPERIMENTAL RESULTS IN PREGNANT FEMALES}

In these experiments, attempts were made to inhibit the normal development of pregnancy corpora lutea or to cause their premature regression, without first causing termination of pregnancy. In the guinea-pig, enlargement of the corpora lutea occurs at the time when ovarian progesterone is most essential for embryonic growth and differentiation, between Days 15 and 20 (Deanesly, 1963). This is, therefore, the best time in which to test substances, such as ergocornine, which may be expected to interfere with luteal cell secretion (Kraicer \& Shelesnyak, 1965).

\section{PROGESTERONE}

Twenty-three guinea-pigs received progesterone tablets on Day 11 of pregnancy and were killed on Day 21 ; progesterone absorption averaged $10.6 \mathrm{mg}$ ( 7 to $19 \mathrm{mg}$ ) over 10 days. At autopsy twenty were normally pregnant, two nonpregnant and one resorbing. The corpora lutea, only measured in two of these females, appeared normal in size (Table 4). Four other animals were given progesterone during different periods of early pregnancy, but without effect on corpora lutea size or development even if treated from the day of the vaginal plug (Day 0) or Day 1. As usual at this stage, cell division could be seen among the lutein cells. Pregnant animals also received $10 \mathrm{mg}$ progesterone daily, in oil, by injection over different periods of early pregnancy (Table 4). Corpora were all of normal size, but in two animals the lutein cells appeared somewhat disorganized.

These results differ from those of Aldred, Sammelwitz \& Nalbandov (1961), who injected relatively large doses of progesterone, $8 \mathrm{mg} / \mathrm{kg}$ body weight, daily, for up to 25 days from the beginning of pregnancy and reported that the mean diameters of the corpora lutea were below normal. This was not found in the present experiments, nor were the follicles affected. 


\section{TESTOSTERONE PROPIONATE}

Tablets were placed in four mated females on Days 9, 10 or 11 after mating and the animals, all pregnant, were killed on Days 20 to 22. Except in the first of these, where the single conceptus showed early signs of regression, corpora lutea were normal in size and appearance (Table 4). The ovaries, however, looked unusually small; the stroma was dense and follicles were neither abundant nor large as in normal pregnancy.

TABLE 4

GORPORA LUTEA IN EXPERIMENTALLY TREATED PREGNANT GUINEA-PIGS

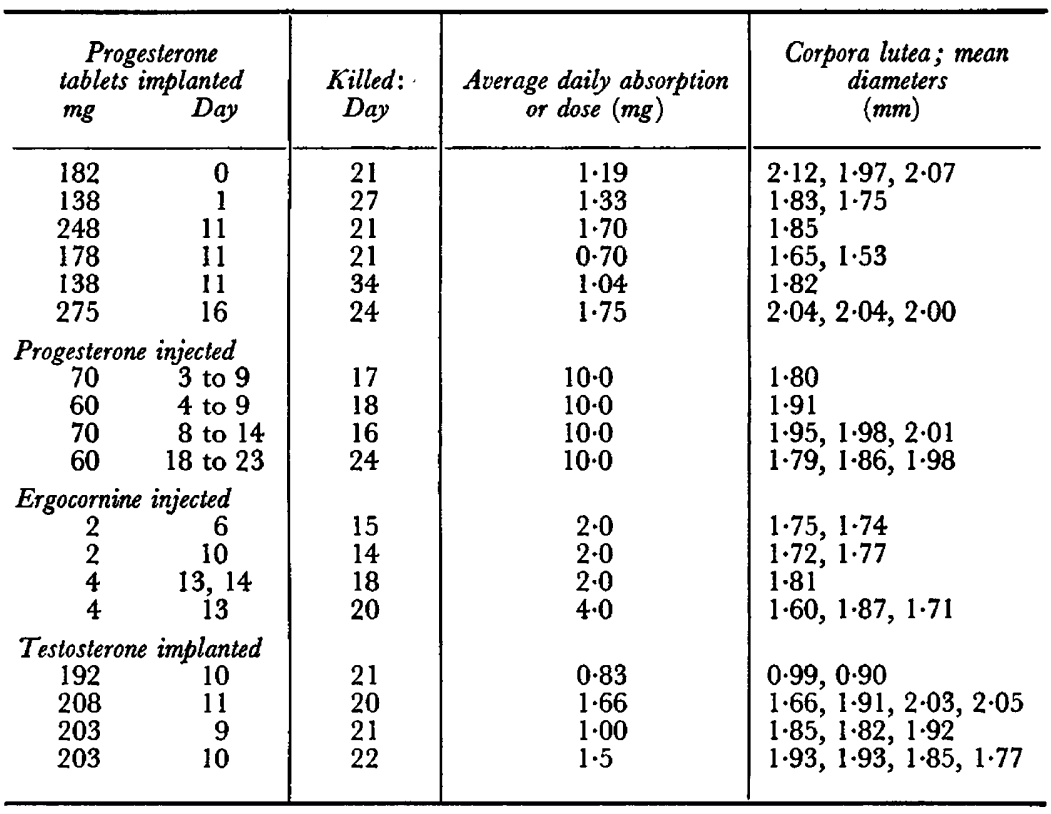

Mean diameters of corpora lutea in normal pregnancy:

16 days: $1.97 \mathrm{~mm}$.

21 days: 1.60 to $2.06 \mathrm{~mm}$ (average of eleven, $1.82 \mathrm{~mm}$ ). 23 to 28 days : 1.74 to $1.92 \mathrm{~mm}$.

\section{ERGOCORNINE METHANE SULPHATE}

Kraicer \& Shelesnyak (1965) reported that ergocornine blocks luteal secretion of progesterone. Six mated guinea-pigs were injected with this substance; the corpora lutea of the four which were pregnant are listed in Table 4. One female had $2 \mathrm{mg}$ on Day 6 and was killed on Day 15, normally pregnant. Two had $2 \mathrm{mg}$ on Day 10; one killed on Day 14 was pregnant, the other on Day 16 had recently ovulated. Two more females had $2 \mathrm{mg}$ ergocornine on Days 13 and 14 and were killed on Day 18; again one was normally pregnant, while the other showed a fresh ovulation. The last female was given $4 \mathrm{mg}$ on Day 13 and was pregnant on Day 20. None of the six showed signs of pregnancy regression.

All pregnant animals in this group had normal corpora lutea and there was 
no indication that ergocornine had effectively checked progesterone secretion at a critical developmental period.

\section{DISGUSSION}

It is clear from these results that $0 \cdot 1 \mathrm{mg}$ or less of progesterone, absorbed daily from solid subcutaneous tablets, will inhibit ovulation indefinitely in cyclic guinea-pigs, without interfering with follicular growth. The effect is primarily on the release of the luteinizing ( $\mathrm{LH}$, ovulation-inducing) gonadotrophin since ovulation can be induced in these experimental animals by the injection of $100 \mu \mathrm{g} \mathrm{NIH} \mathrm{LH.} \mathrm{This} \mathrm{is} \mathrm{in} \mathrm{agreement} \mathrm{with} \mathrm{the} \mathrm{results} \mathrm{of} \mathrm{similar} \mathrm{experiments} \mathrm{in}$ other species (Rothchild, 1965). Evidence that the ovaries of the progesteronetreated guinea-pigs are secreting oestrogen is supplied by the deeply mucified vaginal epithelium, similar to that of pregnancy, which requires both hormones for its presence (Deanesly, 1960). This type of epithelium is absent in ovariectomized guinea-pigs with progesterone tablets.

Progesterone, in the doses used, appears to have no effect on the development, size or duration of cyclic corpora lutea, which showed neither premature regression nor prolongation. In previously reported experiments on hysterectomized guinea-pigs (Deanesly \& Perry, 1965), the vaginal opening occurring during the long luteal phase after removal of subcutaneous progesterone tablets was attributed to corpora lutea secretions having been temporarily checked. It is now known (Heap, Perry \& Rowlands, 1967) that plasma progesterone levels from corpora lutea of hysterectomy are no higher than from cyclic corpora. The vaginal openings presumably occurred because removal of the inhibitory progesterone led to a 'rebound' in gonadotrophin output, followed by increased ovarian oestrogen, corpora lutea activity not being directly affected.

The effects on the uteri of progesterone implanted for a month or longer were not correlated with rates of absorption, but were the reaction to the abolition of normal cyclic changes. The uteri increased in weight, sometimes to a pathological extent, and appeared to be over-stimulated by oestrogens, recalling those in oestrogen-treated guinea-pigs described by Lipschutz (1950) and others. The implanted progesterone does not protect against these changes, as might have been expected, perhaps because, in the non-pregnant female, progesterone never reaches a high concentration in the blood plasma (Heap \& Deanesly, 1967). Pathological enlargement of the uterus is not found in ovariectomized females with progesterone.

The experiments were completed when references to somewhat similar findings in other species were seen in the literature. Lipschutz, Iglesias, Salinas \& Panasevich (1966) observed increase in uterine weight, endometriosis and cystic glands in mice receiving progesterone over 13 months and in six out of twenty-four mice receiving $5.5 \mu \mathrm{g}$ norethinodrel daily for 18 months. For inhibiting ovulation in mice $30 \mu \mathrm{g}$ daily of progesterone will suffice; on a body-weight basis this would correspond to $0.6 \mathrm{mg}$ in a guinea-pig.

Zimbelman \& Smith (1966) noted the effects of melengestrol acetate, a potent progestagen, on cattle. After 3 months' treatment, during which ovulation 
was inhibited, the ovaries contained very large, functionally active follicles. The uterine weights and the swelling of the external genitalia and the increased mucus all indicated a high level of circulating oestrogens.

In the experiments with testosterone no pathological changes were observed in the uteri, although ovulation was inhibited as before. This could be attributed either to the shorter experimental periods, as compared with those of Phelps et al. (1938), or to less oestrogen being secreted from the ovaries than from those in the progesterone series. There appeared to be further gonadotrophin inhibition in this series, presumably of FSH and $\mathbf{L H}$, to judge from the reduction both in ovarian and follicle size. Boling \& Hamilton (1939) had similar results after injecting $4 \mathrm{mg}$ testosterone propionate daily.

No evidence was found of corpus luteum inhibition, similar to that described in rats by Kraicer \& Shelesnyak (1965), in either cyclic or pregnant guinea-pigs treated with ergocornine. This may be explained as due to hypothalamichypophysial differences between the two species already shown in their reactions to reserpine (Deanesly, 1966b) and in particular to differences in corpus luteum maintenance.

In pregnant guinea-pigs, the experimental treatments had no obvious effects on the corpora lutea if pregnancy persisted, a result in agreement with the conclusions of Klein (1939), who found that pregnancy corpora lutea depended on the attached placentae and foetuses and regressed if they were removed, leaving the uterus in situ. Heap, Perry \& Rowlands (1967) reported that corpora lutea were maintained normally in pregnancy after early hypophysectomy, and it is natural, therefore, that they should remain uninfluenced by substances affecting gonadotrophin release.

\section{ACKNOWLEDGMENTS}

The author gratefully acknowledges a grant from the Medical Research Council and the hospitality of the Agricultural Research Council.

Thanks are due to the National Institutes of Health, Bethesda, Md., U.S.A. for a supply of luteinizing hormone NIH-LH-s10 and to Dr M. C. Shelesnyak for the ergocornine methane sulphate.

Miss Carol Smy was responsible for the care and recording of the guineapigs.

\section{REFERENCES}

Aldred, J. P., Sammelwitz, P. H. \& Nalbandov, A. V. (1961) Mechanism of formation of corpora lutea in guinea-pigs. F. Reprod. Fert. 2, 394.

Boling, J. L. \& Hamilton, J. B. (1939) The effect of male hormone substance upon follicular growth and ovulation in the guinea-pig. Anat. Rec. 73, 1.

Deanesty, R. (1960) Endocrine activity of the early placenta of the guinea-pig. F. Endoct. 21, 235.

DEANESLY, R. (1963) Early embryonic growth and progestagen function in ovariectomized guinea-pigs. 7. Reprod. Fert. 6, 143.

DeanesLy, R. (1966a) The effects of purified sheep luteinizing hormone on the guinea-pig ovary. F. Reprod. Fert. 11, 303.

DeANEsLy, R. (1966b) The effects of reserpine on ovulation and the corpus luteum of the guinea-pig. 7. Reprod. Fert. 11, 429.

Deanesly, R. (1966c) Pro-oestrus in the guinea-pig: hormonal stimulation of the vaginal epithelium. F. Reprod. Fert. 12, 205. 
DeANesLy, R. (1967) Normal growth and persistence of corpora lutea of both ovaries in the unilaterally pregnant guinea-pig. 7. Reprod. Fert. 14, 519.

Deanesly, R. \& Perry, J. S. (1965) Corpus luteum control in hysterectomized guinea-pigs. F. Endocr. $32,153$.

Dempsey, E. W. (1937) Follicular growth rate and ovulation after various experimental procedures in the guinea-pig. Am. F. Physiol. 120, 126.

HEAP, R. B. \& DeANesly, R. (1967) The increase in plasma progesterone levels in the pregnant guinea-pig and its possible significance. F. Reprod. Fert. 14, 339.

Heap, R. B., Perry, J. S. \& Rowlands, I. W. (1967) Corpus luteum function in the guinea-pig; arterial and luteal progesterone levels and the effects of hysterectomy and hypophysectomy. 7. Reprod. Fert. 13, 537.

KLEIN, M. (1939) Action du placenta sur le corps jaune gravidique et sur le cycle vaginal chez le cobaye. C.r. Séanc. Soc. Biol. 130, 1393.

Kraicer, P. F. \& Shelesnyak, M. C. (1965) Studies on the mechanism of nidation. XVI. Induction of oestrus by suppression of progesterone secretion by ergocornine. Acta endocr., Copenh. 49, 299.

Lipschutz, A. (1950) Steroid hormones and tumors, p. 79. Williams \& Wilkins, Baltimore.

Lipschutz, A., Iglesias, R., Salinas, S. \& Panasevich, V. I. (1966) Experimental conditions under which contraceptive steroids may become toxic. Nature, Lond. 212, 686.

LOEB, L. (1914) The correlation between the cyclic changes in the uterus and the ovaries in the guineapig. Biol. Bull. mar, biol. Lab., Woods Hole, 27, 1.

LOEB, L. (1932) The parthenogenetic development of eggs in the ovary of the guinea-pig. Anat. Rec. $51,373$.

Nezson, W. O. (1936) Hyperplastic and metaplastic changes in the uterus of the guinea-pig induced by prolonged administration of oestrone. Anat. Rec. 68, 99 .

Parkes, A. S. (1966) The internal secretions of the testis. In: Marshall's Physiology of Reproduction, Vol. 3, chap. 29, p. 501. Longmans Green, London.

Phelps, D., Burch, J. C. \& Ellison, E. T. (1938) Effect of long term injections of testosterone on the guinea-pig endometrium. Endocrinology, 23, 458.

RothCHILD, I. (1965) Interrelations between progesterone and the ovary, pituitary and central nervous system in the control of ovulation and the regulation of progesterone secretion. Vitams Horm. 23, 209.

Zimbelman, R. G. \& Smrth, L. W. (1966) Control of ovulation in cattle with melengestrol acetate. II. Effects on follicular size and activity. F. Reprod. Fert. 11, 193. 